International Journal of Advanced Academic Research (Sciences, Technology and Engineering) | ISSN: 2488-9849 Vol. 6, Issue 8 (August, 2020)|www.ijaar.org

Journal DOI: 10.46654/ij.24889849

Article DOI: 10.46654/ij.24889849.e6819

\title{
ELECTROCHEMICAL BEHAVIOUR OF ANTIMONY MODIFIED CARBIDIC AUSTEMPERED DUCTILE IRON (CADI) IN CHLORIDE ENVIRONMENT
}

\author{
Alao, A. O.; Barnabas A. $A^{2}$; Omole, S. $\mathrm{O}^{2}$; Akinwande, A.A ${ }^{2}$ and Kutelu, B. $\mathrm{J}^{3}$. \\ ${ }^{1}$ Department of Foundry Engineering, Federal Polytechnic, Idah, Kogi State, Nigeria. \\ ${ }^{2}$ Department of Metallurgical and Materials Engineering, Federal University of Technology, \\ Akure, Ondo State, Nigeria. \\ ${ }^{3}$ Mineral Processing Department, Federal Polytechnic, Ado-Ekiti, Ekiti State, Nigeria. \\ Corresponding author: sweetdamse108@gmail.com, barnabelad0110@gmail.com.
}

\begin{abstract}
The effects of austempering temperature on the corrosion behaviour of antimony modified carbidic austempered ductile iron were studied. Rod-like samples of diameter 16mm and 200mm were produced by sand casting method. Six different alloys with equivalent carbon of hypereutectic composition (carbon equivalent of 4.44) were used in order to evaluate the effect of antimony contents ranging from 0.096 to $0.48 w t$. \%. The samples were subjected to austenitic temperature of $910^{\circ} \mathrm{C}$ and austempered at a temperature of $325^{\circ} \mathrm{C}$ on CADI for period of 1 and 3 hrs in chloride environment. Microstructural characterization of the material was made with respect to carbide content and composition, besides their stability during the heat treatment. The results show that the microstructures of the as-cast samples were nodular graphite, pearlite and carbides. The heat - treated samples contained graphite nodules, carbides of varying sizes, ausferrite and retained austenite. With increase in antimony content, the size of nodular graphite decreased. At austempering temperature of $300^{\circ} \mathrm{C}$ with austempering time of 1hour, sample with 0.288 wt. \% of Sb had the least corrosion rate of 2.91E - 05 mmpy while at austempering temperature of $325^{\circ} \mathrm{C}$, CADI sample with $0.192 \mathrm{wt}$ \% Sb had the least corrosion rate of $1.59 \mathrm{E}$ 05 mmpy. It was observed that electrochemical behaviour of these CADI samples in chloride environment was relatively high, though no graphitic corrosion was observed, the corrosion rate of the samples varied with antimony content, at chosen austempering temperatures and times. Therefore, Sb presence in CADI did not deteriorate the corrosion resistance of the CADI, rather there was improvement in resistance.
\end{abstract}

Keywords: Carbidic austempered ductile iron; Microstructure; Carbides; Antimony; corrosion, austempering temperatures of $300{ }^{\circ} \mathrm{C}$ and $325{ }^{\circ} \mathrm{C}$; chloride environment. 


\section{Introduction}

Most materials do experience some interactions with numerous environments often; such interactions degrade materials usefulness as a result of the deterioration of its mechanical properties and other physical properties (appearance). Metals are faced with material loss either by dissolution or by the formation of non-metallic scale or film [1]. Degradation of materials occur every day and this leads to plant shutdowns, wastefulness of valuable resources, product contamination, decrease in efficiency, exorbitant maintenance, and costly overdesign. It also jeopardizes the safety and hinders technological progress [2]. Corrosion is costly and is potentially a life-threatening problem in any industry [3]. The problem of metallic corrosion is of tremendous proportions economy wise, it has been said that nearly 5\% of an industrialized nation's income is usually spent on corrosion prevention, maintenance, and replacement, products lost or contaminated due to corrosion reactions [4].

The best method of increasing austemperability is to increase the alloying element content, although it should be considered that the effects of each element have its own limitations such as reaction delay or ductility reduction. Over alloying is not desirable because of some negative effects. Carbidic austempered ductile iron (CADI) is produced by austempering ductile cast iron that contains carbides; the resulting microstructure will consist of a given volume of carbides within an ausferrite matrix. The volume fraction of carbide present as well as the microstructural scale of the ausferrite can be controlled to provide a range of properties for this material [5].

One of the reasons for longevity of cast irons is that cast-iron sections are thicker normally than their steel counterparts and in earlier times they were over designed, with greater structural reserves to take care of wastage [7]. Graphitic corrosion, normally seen in grey cast iron, in which selective leaching of iron occurs in environments like calm sea water, leaving a graphite network, is not normally observed in austempered ductile iron (ADI) since graphite is present in the form of nodules in ADI, shrinkage or porosity can degrade the corrosion resistance of cast iron parts and the presence of porosity permits the corrosive medium to enter the body of casting. The presence of chlorides does favour the pitting of this cast iron. Pitting of cast iron has been reported $[7,8]$ concerning calm sea water and it has also been reported that additions of nickel to cast iron increase its resistance to pitting corrosion. Microstructural variations in cast irons are said to have much influence on its susceptibility to pitting and crevice corrosion. Severe corrosion of ADI has been attributed to the effect of carbides [9 - 11]. The objective of this work is to study the corrosion behaviour of antimony $(\mathrm{Sb})$ modified $\mathrm{CADI}$ in chloride environment.

\section{Experimental procedure}

\subsection{Sample preparation}

The material used in this study was obtained in a metal casting laboratory, using a $3 \mathrm{~kg}$ capacity electric arc furnace. Cast iron scrap and foundry returns were used as charge materials. In all cases, the melts were nodulized with Fe-Si-Mg ( 9 wt. \% Mg) and inoculated with FeSi $(75$ wt. \% Si). Six alloys of ductile iron were obtained, with $0,0.096,0.192,0.288,0.384$ and $0.48 \mathrm{wt}$. $\% \mathrm{Sb}$. The dimension of each sample cast is $20 \mathrm{~mm} \times 20 \mathrm{~mm} \times 200 \mathrm{~mm}$. 
Table 1

Sample identification, in both the as-cast and heat- treated conditions Identification Heat (\% Sb) Condition Austempering temperature $\left({ }^{\circ} \mathrm{C}\right)$

\begin{tabular}{|c|c|c|c|c|}
\hline Sample code & Heat $(\% \mathrm{Sb})$ & Condition & $\begin{array}{l}\text { Austempering } \\
\text { Temperature }\end{array}$ & $\begin{array}{c}\text { Austempering } \\
\text { time (hrs) }\end{array}$ \\
\hline $1 \mathrm{~A}-1$ & $1(0.192)$ & austempered & 300 and $325^{\circ} \mathrm{C}$ & 1 \\
\hline $1 \mathrm{~A}-3$ & $1(0.192)$ & austempered & $300^{\circ} \mathrm{C}$ and $325^{\circ} \mathrm{C}$ & 3 \\
\hline $2 \mathrm{~A}-1$ & $2(0.288)$ & austempered & $300^{\circ} \mathrm{C}$ and $325^{\circ} \mathrm{C}$ & 1 \\
\hline $2 \mathrm{~A}-3$ & $2(0.288)$ & austempered & $300^{\circ} \mathrm{C}$ and $325^{\circ} \mathrm{C}$ & 3 \\
\hline $3 \mathrm{~A}-1$ & $3(0.384)$ & austempered & $300^{\circ} \mathrm{C}$ and $325^{\circ} \mathrm{C}$ & 1 \\
\hline $3 \mathrm{~A}-3$ & $3(0.384)$ & austempered & $300^{\circ} \mathrm{C}$ and $325^{\circ} \mathrm{C}$ & 3 \\
\hline $4 \mathrm{~A}-1$ & $4(0.480)$ & austempered & $300^{\circ} \mathrm{C}$ and $325^{\circ} \mathrm{C}$ & 1 \\
\hline $4 \mathrm{~A}-3$ & $4(0.480)$ & austempered & $300^{\circ} \mathrm{C}$ and $325^{\circ} \mathrm{C}$ & 3 \\
\hline $5 \mathrm{~A}-1$ & $5(0.096)$ & austempered & $300^{\circ} \mathrm{C}$ and $325^{\circ} \mathrm{C}$ & 1 \\
\hline $5 \mathrm{~A}-3$ & $5(0.096)$ & austempered & $300^{\circ} \mathrm{C}$ and $325^{\circ} \mathrm{C}$ & 3 \\
\hline
\end{tabular}

Austenitizing temperature is $910^{\circ} \mathrm{C}$ for all the samples.

The samples obtained from the five alloys were then heat-treated by austenitizing at $910{ }^{\circ} \mathrm{C}$ and held for 1hour in a muffle furnace followed by an austempering step in a sodium nitrate potassium nitrate salt bath at temperature $300{ }^{\circ} \mathrm{C}$ and $325^{\circ} \mathrm{C}$ at different time of 1 and $3 \mathrm{hrs}$.

\subsection{Chemical and microstructural examination}

The chemical composition of the alloys was determined by means of a Spark Emission Optic Spectrometer with a DV6 excitation source. The chemical composition of the carbides was evaluated by using a FESEM Scanning Electron Microscope with an EDX module, in order to analyse the micro-segregation effects and its influence on the carbide dissolution during heat treatment.

\subsection{Electrochemical Test}

Corrosion test was conducted using potentiodynamic polarization electrochemical methods in accordance with ASTM G57-97 (2014) standard. The experiment was carried out using Versa Potentiostat. Corrosion behaviour of the samples was investigated in chloride environment at 
ambient temperature $\left(25^{\circ} \mathrm{C}\right)$. Potentiodynamic polarization measurement was carried out using a scan rate of $0.1666 \mathrm{mV} / \mathrm{s}$ at a potential initiated at $-200 \mathrm{mV}$ to $+250 \mathrm{mV}$. Two repeated tests were carried out for all compositions of the alloys, and the reproducibility and repeatability were observed to be reasonably good as there were no significant differences between results from duplicates. Corrosion rate was calculated using penetration rate (C.R). The equations stated below according to Mansfeld, 1972 were used to calculate the penetration rate (C.R).

C.R is $\frac{K i \times I c o r \times E W}{\rho}$

C.R is given in $\mathrm{mm} / \mathrm{yr}, \mathrm{I}_{\text {corr }}\left(\mu \mathrm{A} / \mathrm{cm}^{2}\right)$,

$$
\mathrm{Ki}=3.27 \times 10^{-3}(\mathrm{~mm} \mathrm{~g} / \mu \mathrm{A} \mathrm{cm} \mathrm{yr}),
$$

\section{Results and discussion}

\subsection{Chemical and microstructural characterization}

Table 2: Chemical Composition for the Produced Samples Evaluated (wt. \%)

\begin{tabular}{ccccccccccccc}
\hline Alloy No & $\mathbf{F e}$ & $\mathbf{C}$ & $\mathbf{S i}$ & $\mathbf{M n}$ & $\mathbf{C r}$ & $\mathbf{N i}$ & $\mathbf{C u}$ & $\mathbf{M g}$ & $\mathbf{S b}$ & $\mathbf{S}$ & $\mathbf{P}$ & $\mathbf{C . E}$ \\
\hline $\mathbf{1}$ & 89.39 & 3.62 & 2.42 & 0.58 & 2.6 & 0.60 & 0.69 & 0.06 & - & 0.004 & 0.040 & 4.43 \\
$\mathbf{2}$ & 89.33 & 3.62 & 2.40 & 0.57 & 2.61 & 0.61 & 0.65 & 0.07 & 0.096 & 0.005 & 0.041 & 4.43 \\
$\mathbf{3}$ & 89.24 & 3.62 & 2.41 & 0.57 & 2.62 & 0.62 & 0.61 & 0.07 & 0.192 & 0.005 & 0.042 & 4.44 \\
$\mathbf{4}$ & 89.19 & 3.63 & 2.40 & 0.56 & 2.60 & 0.60 & 0.62 & 0.07 & 0.288 & 0.005 & 0.042 & 4.44 \\
$\mathbf{5}$ & 89.10 & 3.62 & 2.41 & 0.56 & 2.63 & 0.61 & 0.62 & 0.06 & 0.384 & 0.005 & 0.040 & 4.44 \\
$\mathbf{6}$ & 88.97 & 3.62 & 2.40 & 0.58 & 2.62 & 0.60 & 0.63 & 0.06 & 0.480 & 0.004 & 0.041 & 4.43 \\
\hline
\end{tabular}

Hyper-eutectic composition (carbon equivalent, C.E is 4.44). 
International Journal of Advanced Academic Research (Sciences, Technology and Engineering) | ISSN: 2488-9849 Vol. 6, Issue 8 (August, 2020) | www.ijaar.org

Journal DOI: 10.46654/ij.24889849

Article DOI: 10.46654/ij.24889849.e6819

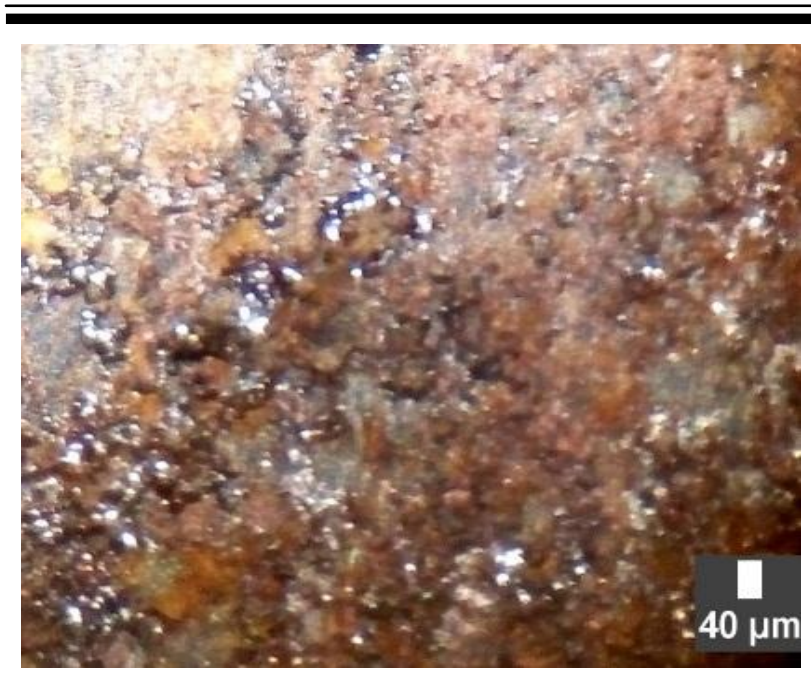

Plate 1: Stereo-micrograph of the unmodified sample showing more of uniform corrosion.

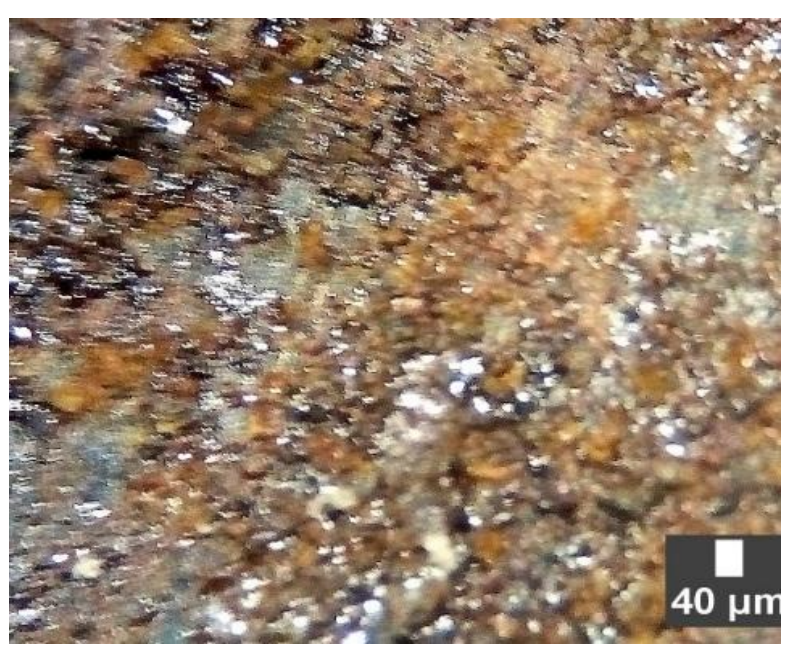

Plate 2: Stereo-micrograph of the representative modified samples showing uniform corrosion.

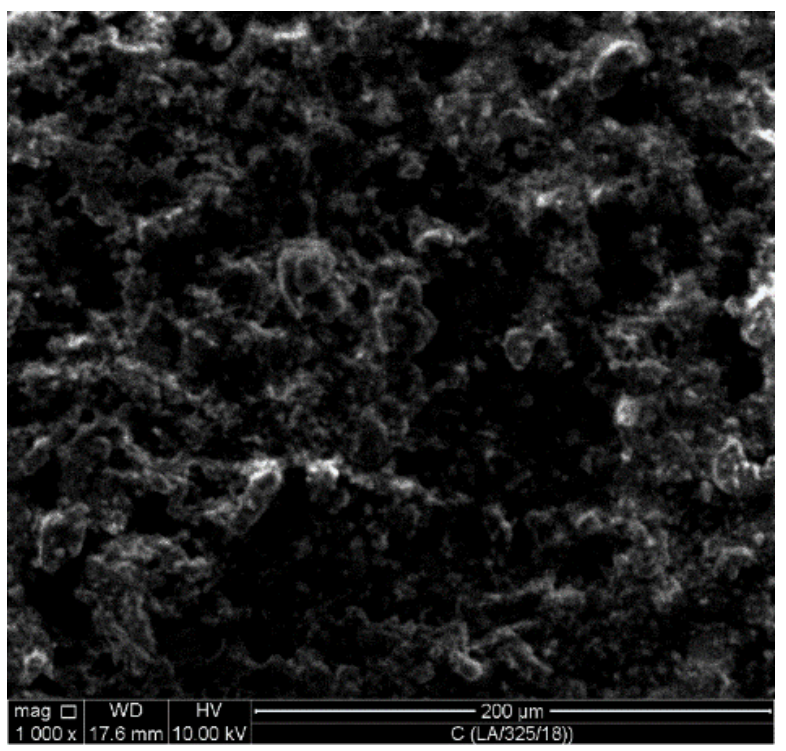

Plate 3: Secondary Imaging mode of SEM of Plate 4: Representative sample of the modified Unmodified CADI

CADI showing exfoliated corrosion product

Plate 1 -2: This suggested that the process (and probably the rate) of general corrosion on the surface of the produced CADI was strongly influenced by the local exposure condition.

Plates 4 revealed exfoliated corrosion products formed on CADI Sample been exposed to $3.5 \%$ $\mathrm{NaCl}$ solution, while Plate 3 showed un-exfoliated corrosion products of the control sample. 
International Journal of Advanced Academic Research (Sciences, Technology and Engineering) | ISSN: 2488-9849 Vol. 6, Issue 8 (August, 2020)| www.ijaar.org

Journal DOI: 10.46654/ij.24889849

Article DOI: 10.46654/ij.24889849.e6819
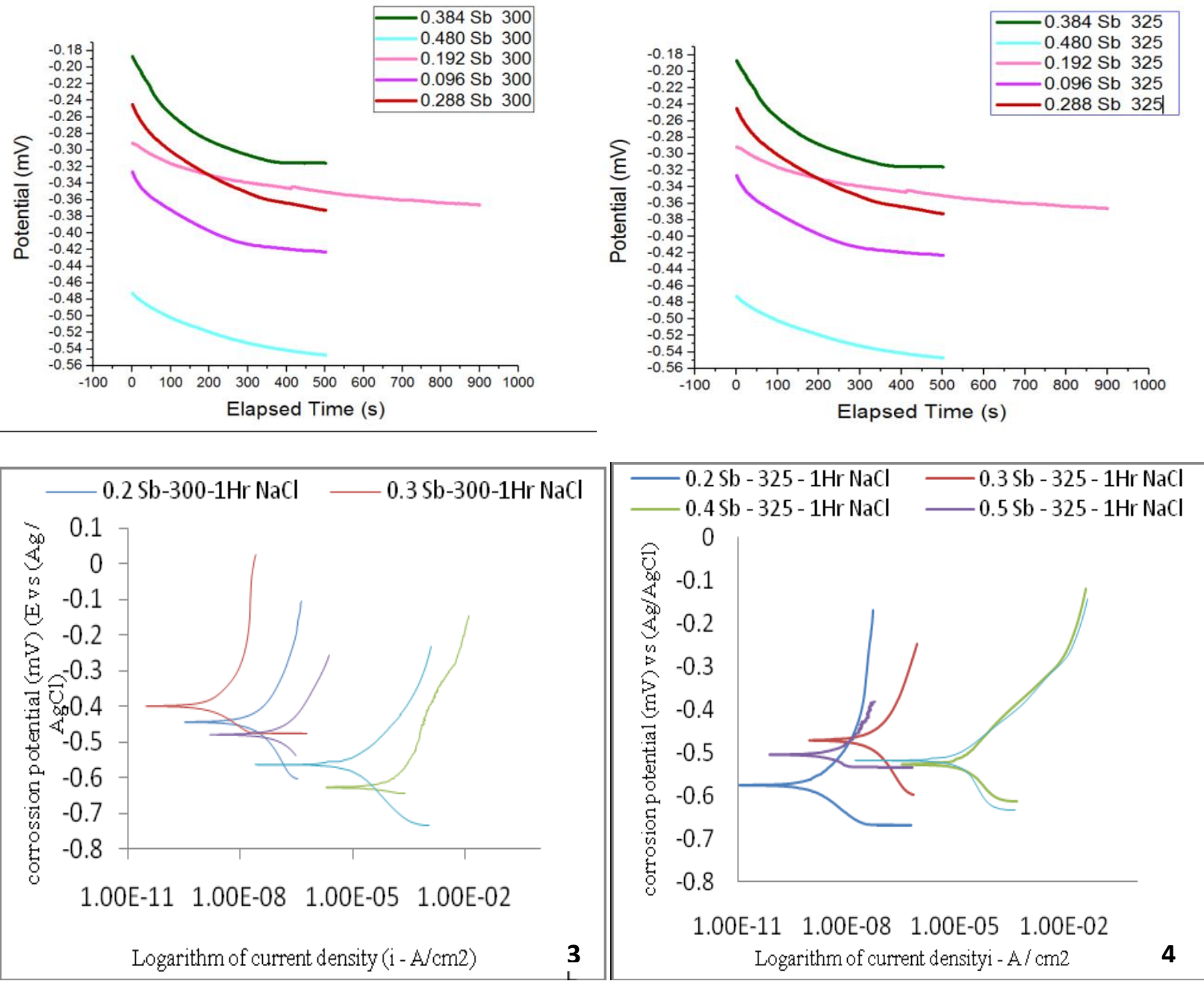


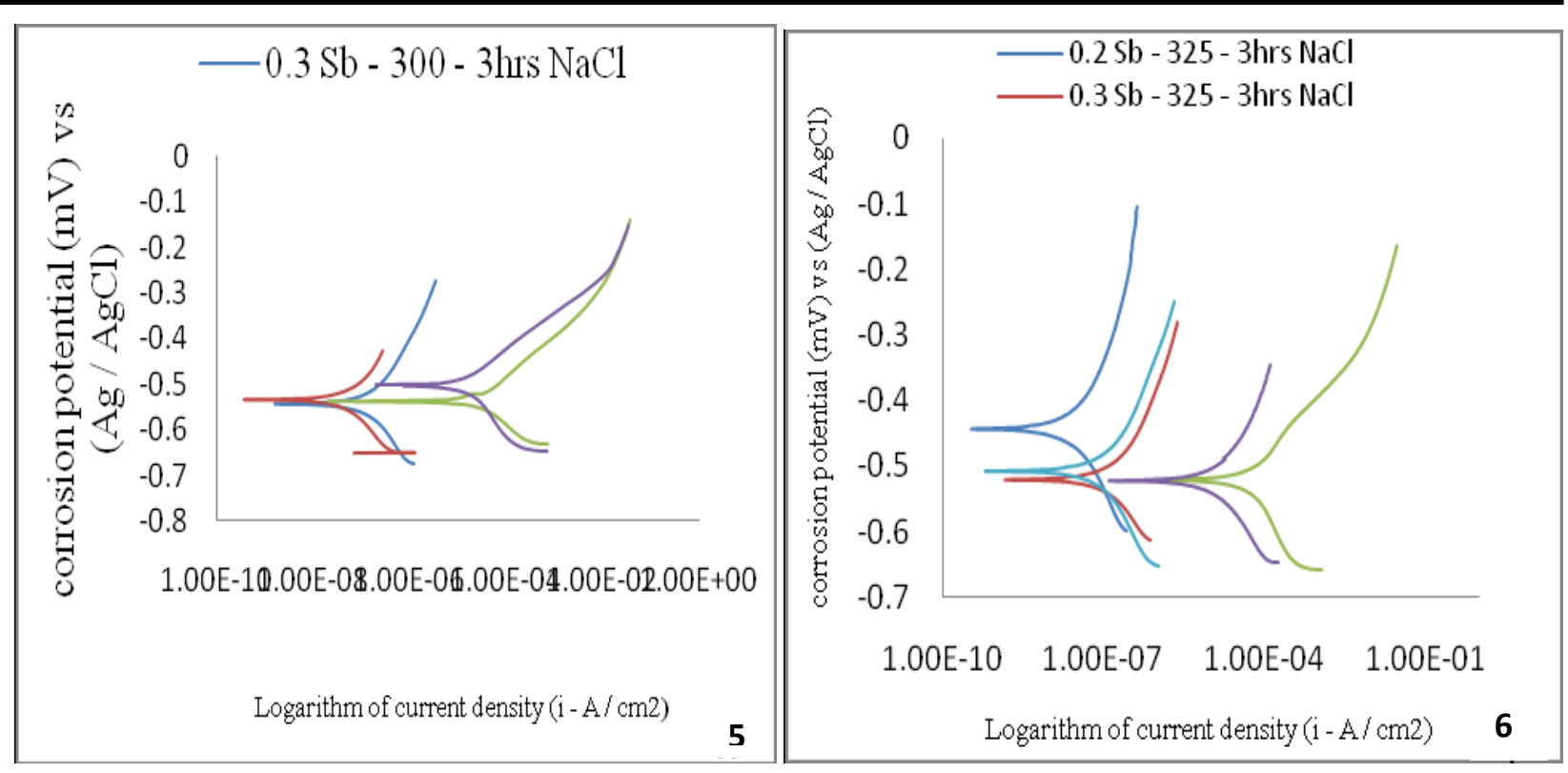

The specimens exposed to $3.5 \% \mathrm{NaCl}$ solution (sea water simulated), has corrosion potential that does not seem to follow a definite trend and it appears to be established around - $500 \mathrm{mv}$ CADI sample with antimony content of $0.192 \mathrm{wt}$ \% heated to austempering temperature of $300{ }^{\circ} \mathrm{C}$ held for 1 hour has the least potential indicating that its least corrosion kinetics compare with the other samples, which could be as a result of microstructural variation of the specimens. Meaning that, the corrosion rate of this cast iron was seen to be influenced by the carbide morphology (size), and volume fraction of the phases of the microstructure (Mehra and Soni, 2011). The presence of chlorine in the environment increases the conductivity of the solution and promotes dissolution of iron. Hence, the iron ions concentration in $\mathrm{NaCl}$ solution is high, causing the ions to react with oxygen and drive the corrosion process. It can be observed that the specimens exposed to this environment show similar behavior in the shape of their cathodic and anodic curves in spite of the variation in their microstructures and corrosion potential and no distinctive pattern is seen between the plots for different shapes of the produced CADI.

Both the modified and un-modified samples exposed to this $3.5 \% \mathrm{NaCl}$ solution displayed relatively high corrosion rate which is in accordance with Shreix et al. (1994). It was observed that the corrosion mechanism is controlled by ion species through the existing oxide layer. The thicker the oxide layer, the more difficult it is for the ions to diffuse in and out, because of the thick oxide layer formed on the surface of some of the samples. The formation of $\mathrm{Fe}_{3} \mathrm{O}_{4}$ as a result of solubility of $\mathrm{Fe}^{2+}$ to $\mathrm{Fe}^{3+}$ and $\mathrm{FeCl}_{3}$ in chlorine rich environment was generally expected (Shreir et al., 1994).

The variation in the open circuit potentials (OCP) of the produced CADI exposed to $3.5 \%$ sodium chloride environment is presented in Figures 1 and 2. It was observed that OCP profile of the produced CADI samples austempered at temperature of $300{ }^{\circ} \mathrm{C}$ period of 1 hour decreases 
continuously, until a steady state was attained. The steady OCP values observed in the corrosion process of the CADI is typical of materials systems undergoing formation of passive film and breakdown of the film due to its exposure to corrosive environment. On observation of the OCP profiles of the CADI in these alloys, it is noted that CADI with 0.288 wt. \% Sb had the highest OCP value in comparison with the other CADI grades. This suggests that CADI with 0.288 wt. $\%$ $\mathrm{Sb}$ will have the least thermodynamic tendency to corrode in the chloride environment. While CADI samples with austempering time of 3 hours, containing 0.096 wt. \% Sb seems to have higher thermodynamic stability and hence a lesser tendency to corrode in chloride environment in comparison with the CADI containing more amounts of antimony. It is noted that some of the CADI sample with antimony addition austempered at austempering temperature of $300{ }^{\circ} \mathrm{C}$, held for periods of 1 and 3 hours, had higher OCP values in comparison with the CADI samples without antimony addition. This again shows that some of the CADIs have a lower thermodynamic tendency to corrode in $\mathrm{NaCl}$ solution in comparison with $\mathrm{CADI}$ without antimony addition (control sample).

For austempering time of 1 hour, it is further noted that CADI sample with $0.288 \mathrm{wt}$. \% Sb had the least corrosion rate. This observation is consistent with the results from the OCP values as earlier discussed.

In the case of the CADI samples austempered at austempering time of 3 hours, CADI with 0.48 wt. \% antimony elements had the least corrosion rate among the other CADI samples of varying antimony content. It was clear that addition of antimony element in the CADI samples helped in improving the corrosion resistance of the CADI but varied with the austempering time of the produced CADI in chloride environment. Antimony addition did not degrade the corrosion properties of the produced CADI. Also, high nickel content in the produced CADI immersed in $3.5 \mathrm{NaCl}$ solutions helped to prevent pitting corrosion (Morgan, 1990) (Talbot, 1999).

The potentiodynamic polarization curves for the composites in $3.5 \mathrm{NaCl}$ solutions, Figures 3 - 6 helped in analyzing more thoroughly the corrosion behavior of the CADI alloys. Figures 3 6 shows that the composites generally displayed similar polarization curves and passivity characteristics. It is seen clearly that the corrosion potentials Ecorr. and corrosion current density Icorr of the composites did not follow a consistent trend with variation in wt $\%$ of antimony addition in the alloys produced as with the case with the OCP curves. Among the carbidic ductile irons (CDI) containing antimony content ranging from 0.096wt.\%, 0.192wt.\%, 0.288wt.\% , $0.384 \mathrm{wt} . \%$ and $0.48 \mathrm{wt} . \%$ produced without heat treatment, CDI with antimony content of $0.41 \mathrm{wt} . \%$ has the highest open circuit potential and consequently the least corrosion rate value, signifying the influence of antimony on the CDI. This indicates that the CADI sample with $0.31 \mathrm{wt}$. \% antimony composite has lower corrosion susceptibility in $3.5 \mathrm{wt} \mathrm{NaCl}$ solution in comparison with the higher reinforced grades. For austempering time of 1 hour, it is further noted that CADI sample with $0.31 \mathrm{wt}$ \% $\mathrm{Sb}$ had the least corrosion rate. This observation is consistent with the results from the OCP values Figurela as discussed earlier. In the case of the CADI samples austempered at austempering time of 3hours, CADI with 0.48 wt. \% antimony elements had the least corrosion rate among the other CADI samples of varying antimony content. It was clear that addition of antimony element in the CADI samples helped in improving the corrosion 
resistance of the CADI but varied the austempering time of the produced CADI in chloride environment. Antimony addition does not degrade the corrosion properties of the produced CADI in $3.5 \mathrm{NaCl}$ solutions.

\section{Conclusion}

Antimony modified carbidic austempered ductile iron (CADI) with different amount of antimony content was developed. The antimony contents ranged between 0.096 and 0.48 wt. \% were produced by sand casting method.

The best sample obtained is high nickel-manganese carbidic austempered ductile iron with antimony critical content of $0.288 \mathrm{wt} \%$. The following conclusions were made:

(1) CADI samples exposed to $3.5 \% \mathrm{NaCl}$ solution formed exfoliated corrosion products

(2) The Open Circuit Potential of the CADI samples in chloride environment does not seem to follow a definite trend and it appears to be established around $-500 \mathrm{mV}$

(3) CADI sample with antimony content of $0.192 \mathrm{wt} \%$ subjected to austempering temperature of $300^{\circ} \mathrm{C}$, held for 1 hour had the least corrosion potential.

(4) The corrosion rate of the antimony modified CADI in chloride environment was observed to be influenced by antimony content. 


\section{REFERENCES}

[1] Callister, W. D. (2001): Fundamentals of Materials Science and Engineering. John Wiley and Sons, Incorporation, New York. Pp $69-185$.

[2] Pierre R. Roberge, 2000: Handbook of Corrosion Engineering, McGraw-Hill, Pp 1140

[3] Mehra R. and Soni A., 2002: Cast iron deterioration with time in various aqueous salt solutions, Bulletin of Materials Science, Vol. 25, Pp. 53-58.

[4] Shreir, L. L. Jarman, R. A. and Burstein G. T., (1994): Corrosion, Butterworth Heinemann, Oxford, UK, 3rd edition,

[5] Morgan, N.: (1990): Marine technology reference book, Vol.8, Pp1 - 22; London, Butterworths.

[6] Talbot, D. and. J. Talbot (1999): Corrosion Science and Technology, Pp 251-258;

New York, NY, CRC.

[7] Hayrynen. K, Brandenberg. K., (2003): Carbidic Austempered Ductile Iron the New Wear Material, Transaction of American Foundry Society, 111, Paper No. 03-88, Pp 845-850.

[8] Beccaria A.M., Poggi G., and Castello G. (1995): Brazilian Corrosion Journal, Pp 283299, Vol. 30, Issue 4.

[9] Asami K and Hashimoto K (1977): Corrosion Science, pp. 559-570, Vol. 17

[10] Beccaria A.M, Poggi G, Gingaud D and Castello G (1994): Brazilian Corrosion Journal, pp 65-69, Vol. 29, Issue 1.

[11] Beccaria A.M, Poggi G. (1987): Corrosion Prevention Control, pp. 51-57. 